$11-17-2017$

\title{
Freirean Pedagogy in Beirut's Migrant Worker Classroom
}

Shireen Keyl

Utah State University

Follow this and additional works at: https://newprairiepress.org/piper

Part of the Bilingual, Multilingual, and Multicultural Education Commons

\section{Recommended Citation}

Keyl, S. (2017). Freirean Pedagogy in Beirut's Migrant Worker Classroom. Pedagogy \& (Im)Possibilities across Education Research (PIPER), 1 (1). https://doi.org/10.4148/2576-5795.1001

This Article is brought to you for free and open access by New Prairie Press. It has been accepted for inclusion in Pedagogy \& (Im)Possibilities across Education Research (PIPER) by an authorized administrator of New Prairie Press. For more information, please contact cads@k-state.edu. 


\title{
Freirean Pedagogy in Beirut's Migrant Worker Classroom
}

\begin{abstract}
This article is based on a three-month ethnographic study conducted in a non-governmental organization (NGO) in Beirut, Lebanon. This particular NGO, in conjunction with other organizations, provides educational opportunities for migrant domestic workers: adult language classes for learning English and French. The volunteer teachers have no pedagogical or instructional training, and often no previous teaching experience. By way of participant observation and in-depth interviews, I examine the narratives of volunteer teachers who describe a Freirean pedagogical position that is also evident in their teaching practices. I assert that a Freirean model for NGO functionality can bring about liberatory and transformative education and a successful NGO structure.
\end{abstract}

Concepts, Ideas, People

Paulo Freire, Non-governmental organization, Beirut, Lebanon, Transformative education, Migrant domestic workers

Epistemologies, Methods, and Theories

Participatory Action Research (PAR), Ethnographic Methods, Critical Theory 


\section{Introduction}

Educational opportunities for migrant workers in the Middle East region are largely absent. While a necessary topic, most literature regarding labor migration in the Gulf region and Middle East focuses on human rights atrocities such as human trafficking, domestic servitude, abuse, and premature death. While the development literature is abundant with discussion regarding education from a policy and management standpoint in developing countries, any discussion specifically regarding migrant workers and education in the Middle East region centers on educational level attained pre-migration. This study attempts to fill that gap by offering a perspective on the ideological, pedagogical and curricular practices of teachers volunteering in a non-governmental organization (NGO) in Beirut, Lebanon. Such an examination can offer to the development sector and development studies an exemplary for how to "do" education for marginalized groups. This article sheds light on the Freirean pedagogical perspectives of the volunteer teachers, informs ideas about activism and empowerment in the educational space, and suggests a Freirean framework for non-governmental organizations in their management and educational endeavors.

This study is based on fieldwork conducted at a grassroots non-governmental organization (GNGO) in Beirut, Lebanon to learn about the ideological underpinnings of these particular NGOs and volunteer groups. This study sought to learn about the pedagogical and instructional practices of the volunteer educators; I also desired to gauge the educators' ideas about activism and volunteering and how these ideas informed their pedagogical practices. In what follows is an examination of the narratives of teachers and an analysis of how these teachers' practices exemplify Freirean pedagogy.

\section{NGOs in the Middle East}

Throughout the Middle East region an Asian countries, NGOs provide a range of social and legal services for marginalized groups. The women who receive services at these NGOs come from many different walks of life; in Lebanon, some migrant women flee conflicts of war in their home countries, while other women escape impoverished conditions. The types of services rendered within the development sector and under the NGO umbrella are largely dependent upon the organizational structure assessing the needs of local populations. For instance, grassroots movements are more organic in their organization and ideology, and, therefore, tend to have an understanding of the "on the ground" issues of the populations they serve. In India, maternal and reproductive health is an important public health issue; thus, there are several NGOs that focus on this goal and provide workshops for women to teach them about sexual and reproductive health ("Bella Health: About", 2013). In Afghanistan, American and Afghan stakeholders (e.g., Afghan youth and civic leaders, American military members, and some Afghan government officials) determined that the promotion of civil engagement between Western nations and Afghanistan would be expedient for the promotion of greater social and 
political awareness, and as a result, NGOs with this goal have been established ("CVI Focus Areas", 2013). In Iran, a gap existed in the allocation of social and educational services for females from backgrounds of abuse and neglect, and this resulted in a women's center being established for this demographic ("Omid Foundations", 2013). Other criteria that impact the delivery of services are funding, local politics, manpower, and geographical location. Within the development sector the goal of NGO educational opportunities is to provide a formalized classroom experience within a traditional educational structure.

In Lebanon, there are several established NGOs that have been providing social and legal services to vulnerable populations; one such group is the Amel Association, which is an advocacy group for Lebanon's most vulnerable populations, such as children, refugees, and migrant workers. In 2011, the Amel Association began an initiative to provide legal protection to migrant workers and assist them in returning to their home countries ("Migrant Domestic Workers Project," n.d., para. 3). The Caritas Lebanon Migrants Center, established in the 1990s, began its outreach efforts by providing for asylum seekers and refugees direct aid and legal assistance; since then, Caritas has begun offering more legal and medical aid earmarked specifically for female domestic workers, especially those who have been imprisoned illegally and in violation of their human rights ("Caritas Lebanon: Migrants Center," n.d., "objective").

In recent years, the NGO network in Lebanon has been recognizing the plight of migrant workers, especially female migrant workers, and has been filling the void of legal and social assistance, as evidenced by the pioneering work of such organizations as Amel and Caritas. A recent development within Lebanon's migrant NGO and grassroots network is the offering of educational opportunities, such as English classes, French classes, and computer classes for adult migrant workers. It is within this educational context in the space of the Migrant Center this study performs: to learn about the pedagogical frameworks from which the NGOs and volunteer teachers operate in meeting the needs of the populations they serve. What makes this grassroots NGO different in its function, compared to other NGOs? How do the teachers teach? Why do they teach the way they do, and what exactly is the purpose of an educational NGO for migrant workers?

What prompted this examination of educational practices within this Lebanese NGO was my previous experience teaching in an Iranian Women's Center that also provided educational opportunities. I had noticed that the Afghan refugees who attended the center frequently felt marginalized compared to their Iranian counterparts, their voices silenced when they complained about discrimination, and classroom practices that often left the Afghan students' educational needs unmet, while the Iranian students were favored. In a space that is supposed to empower women, the Afghan students frequently felt disempowered. In light of my observations at this Iranian NGO, I sought to examine the educational functionality of the Beirut NGO system through a Freirean lens. 
In the following, the theoretical context of this study is discussed to help in framing my own lens and positionality as I entered the research site.

\section{A Freirean Positionality: A Critical Framework}

Paulo Freire, the critical pedagogue and educator whose seminal work, Pedagogy of the Oppressed (1970) is significant to the education of oppressed peoples. Freire was born into a middle-class family in Brazil in 1921. As a child, his family experienced poverty, and Freire became acquainted with acute hunger; these early experiences became the basis of his understanding of class politics and shaped a world view that would greatly influence his future ideological framework, known as critical pedagogy. Freire's early work is based on his teaching experiences in his Native Brazil where he founded a national literacy campaign and taught literacy skills to peasant-laborers and slum dwellers. What differentiated Freire from other educators of his day was the incorporation of a socialist perspective he brings into the science of teaching and learning. Pedagogy of the Oppressed is not just an analysis of a traditional, authoritarian system of education, but a political critique that links the passivity of the masses to a system of education that is representative of neoliberal policies. In sum, Freire challenges the dominant power structures that influence the way we draw conclusions about knowledge.

\section{Why Freire?}

I have been a teacher in different educational contexts: in public school settings in the United States and in non-governmental settings in both Iran and Lebanon. My American and Iranian nationalities have created for me complex layers of identity politics as an American teacher in the Middle East context and as a Middle Easterner in United States context, which is made more complicated by my belief in being real and transparent with my students. It was my learning about Freire's educational philosophy that helped me to the hard work of confronting and reconciling my dueling identities to be an authentic educator; in a sense, it was Freire that helped me to come to terms with my heritage, which is often fraught with political and religious binaries.

As someone who identifies as a critical educator, and values the libratory ideology put forth by Freire's work, I view the classroom as a microcosm of the larger society; it is difficult not to see the injustices at the macro level replicate in the institution of education and the classrooms within that institution. In my own experiences as an educator, whether in a $4^{\text {th }}$ grade classroom in rural Montana or an EFL teacher of adult migrant students in Lebanon, the teaching mechanism is empowered by using as a vehicle a pedagogy of anti-oppression: a transformative model of education for empowerment for all oppressed peoples. As I transitioned to a teaching and research role in higher education, this lens for interpreting the world has only been made stronger as I became exposed to and learned from the ideological groundings of critical theories in all their manifestations: decolonial frameworks, third world feminisms, critical spatial analyses, and Freirean philosophy. More than ever, I see the urgency in incorporating this 
critical worldview in teacher education in addition to international development educational frameworks.

As a qualitative researcher, my methodology is greatly influenced by Freire as well; in the following, I will outline my research paradigm and highlight Freire's influence within it.

\section{Research Methodology: Participatory Action Research (PAR)}

Several scholars have contributed to the merging of research methodologies and social justice initiatives. The educational outreach of Freire is considered to have laid the groundwork of participatory research and is largely cited by several leading critical scholars and PAR studies as being a transformative educational approach (Creswell, 2014, p. 9; Denzin and Lincoln, 2011, p. 550; Minkler and Wallerstein, 2008, p. 38; Kapoor and Jordan, 2009, p. 124-125; DuncanAndrade and Morrell, 2008).

To be sure, like any research paradigm, PAR has its share of critics, who of which consider PAR to be biased; not "pure" in terms of its methodology; and as such, it is "rarely taught in our leading postsecondary institutions" (Duncan-Andrade and Morrell, 2008); however, if its greater objective is to meld a theory with practice and to produce results which are not solely for the benefit of the researcher, but on the contrary, are meant to be empowering for the participants' communities, than a "purist", postivitist/post positivist position holds little place in a researcher's motivation. In fact, PAR is working against the failure of the institution (be it educational, health care, social work, and so on) "to decolonise the underlying ideological impulse that administers our professional imaginations" which have the tendency to "(re) produce a narrowly individualistic and pragmatic paradigm...PAR is an open and interconnected approach, one that is unashamed of its political and ideological foundations and is constructed through relationships to the 'other' as defined by shared place-based interests" (Hunter et al., 2013, p.8). Budd Hall, a leading PA researcher, asserts that participatory research is "a practice that attempted to put the less powerful at the center of the knowledge process; to move people and their daily lived experiences of struggle and survival from the margins of epistemology to the center" (1992, p. 15-16). This study's methodology exemplifies privileging the participants' epistemological conributions in the research process.

In sum, my aim as a researcher and as a critically conscious human being is to contribute to a body of knowledge which first and foremost honors the voices and lives of those who share their stories with me; as an educator, I aim to continue to serve those groups who desire educational opportunities, and I will continue to practice a libratory pedagogy with all groups, especially the marginalized and oppressed. It is my hope to bring front and center the epistemologies of the oppressed. 


\section{Context: The Migrant Workers Educational Group}

In 2012, I spent three months as a researcher-practitioner at the Migrant Center (MC), a community center in Beirut, Lebanon. The Migrant Center was established by the Migrant Worker's Educational Group (MWEG), a grassroots organization whose purpose is to provide educational opportunities to migrant workers by recruiting volunteer teachers to teach language classes and computer classes to migrant workers. During the time that I was there, I was a participant observer, teaching English classes and helping as an assistant to the center coordinator. The language classes offered during my time with MWEG were English and French. MWEG does not have its own educational space so it relies on the generosity of local groups to provide a space; hence, the Migrant Center provides the space for MWEG to hold classes.

According to their website, MWEG defines itself as "a grassroots volunteer organization that leads initiatives for better treatment and social advancement of the migrant worker community in Lebanon" with the aim "to improve the situation of migrant workers in Lebanon through grassroots initiatives" by way of offering educational opportunities such as English and French classes as well as computer classes ("Migrant Workers Task Force: Our Mission", n.d.). MWEG is comprised of three separate volunteer groups who run autonomously of each other in different centers in Beirut yet operate under the MWEG umbrella. For the purpose of this study, I volunteered as an English teacher so I could provide continuity as an educator by having the same group of students every week and to be connected to my research site, the Migrant Center.

\section{Data Collection Tools and Data Analysis}

This qualitative research study utilized in-depth interviews, focus groups, and participant observation. In obtaining informed consent, I asked the research participants for their permission to record their voice and persmission to use the interview to inform my written research. The names of the research participants at the focus of this study have been changed and pseudonyms are used to protect the anonymity of participants. Interviews were transcribed and in analyzing my data, I utilized grounded theory, which consists of '...[S]ystematic, yet flexible guidelines for collecting and analyzing qualitative data to construct theories 'grounded' in the data themselves' (Charmaz, 2006, p. 2-3). A grounded theory approach values posteriori knowledge, or knowledge dependent on experience. As one who advocates for the utilization of grounded theory, I adopt a posteriori justification when entering the research field and conducting fieldwork.

Grounded theory does not aim to make generalizable claims "abstracted from empirical realities"; rather, the strength of grounded theory situates "grounded theories in their social, historical, local and interactional contexts" which strengthens theorizing claims that emerge and allows for "making nuanced comparisons between studies" (Charmaz, 2006, p. 180). This study 
aims to provide a description of a grassroots educational NGO's curriculum and pedagogy practices to explain how knowledge production and power are intertwined and create libratory and resistance frameworks that function in educational and community spaces.

In the following, I will describe my data collection methods.

\section{In-depth interviews}

The in-depth interviews took place throughout the three months I conducted fieldwork. Research participants were the volunteer teachers and NGO coordinators. Teachers and coordinators were interviewed at a place of their choosing, such as at a restaurant, on the campus of Lebanese American University, at the MC, or at their own homes. As a starting point, I used a list of questions from this to begin the interview; however, the in-depth interview does not work off of a script of questions. On the contrary, the interview process is an organic process, one in which the interview becomes a dialogue, a space where the participant feels safe to share his or her lived experiences and her reflections on those experiences; "The in-depth interview is not to get answers to questions, nor to test hypotheses, and not to 'evaluate' as the term is normally used. At the root of in-depth interviewing is an interest in understanding the lived experience of other people and the meaning they make of that experience" (Seidman, 2006 , p. 9). I use the in-depth interview as a tool to allow for a reciprocal and dialogic discussion to take place and allow space for agency so the participant can speak freely, asking me questions as well during the course of our conversation.

\section{Focus groups and participant observation}

A portion of this research project took place in the space of the MC, at which I spent time every day, and in my classroom space on Sundays where I taught English. It is within these spaces that I utilized the research methods of participant observation and the focus group, which I will now discuss.

Ethnography, according to Brice-Heath and Street (2008, p. 31), "forces us to think consciously about ways to enter into the life of the individual, group, or institutional life of the 'other'". By applying an ethnographic lens as a researcher in the classroom, my aim was to (with the permission of my participants) become aware of the attitudes, opinions, and ideas of the students in my class. Participant observation helped me understand how the students drew conclusions about knowledge and what informs their knowledge base (e.g., How do their lived experiences inform the ways they interpret the world? How do they use the advice given to them by friends and family? How do they use their formal and/or informal educational experiences?). The students in the classroom formed the focus group. Because I desired to create a healthy dialogic space in which an exchange of ideas, opinions, questions and contributions can occur, my critical pedagogical stance as an authentic educator encouraged this dialogic space and the building of trust and relationships. 


\section{NGO education through the eyes of volunteer teachers}

The teachers for MWEG are all volunteers and they are recruited from the Lebanese American University located in Beirut. When I was volunteering as a teacher for MWEG, there were ten volunteer teachers: six were of Lebanese heritage; one teacher was from Syria; and, the remaining three were from either Europe or the United States. Besides myself, all of the teachers were undergraduate students or had only completed their undergraduate studies, with the exception of Sofia, who was Italian and a graduate student in Islamic Studies, and Omid, a student attending medical school. While none of the teachers were education majors or had any formal training in pedagogy or teaching methods, most had prior formal and/or non-formal teaching experiences. For instance, 21-year-old Omid, a Lebanese student who is in medical school, has held sexual health and education workshops for migrant workers and HIV+ seminars for Beirut's gay population. Roby is 26 years old and he is originally from Syria. He has a bachelor's degree in pharmacy and has been living in Beirut due to the civil war in his country. He volunteers for the Red Crescent in Beirut and is looking for work with international non-governmental organizations. All classes with MWEG are offered on Friday nights and Sundays only because these are the days off typically given to domestic workers. MWEG has been providing computer and language classes since January 2011; At the time of this fieldwork, MWEG was providing educational opportunities to 130 migrant workers at their three locations. ${ }^{1}$

In the following sections, I present my observations of the teaching space and the narratives of the teachers. I then organize this data to reflect the common themes that arose in the data analysis that speak to issues of libratory and transformative educational practices.

\section{Volunteer teachers' understanding of migrant issues}

Usually on Sundays prior to teaching, we would hold a teacher meeting to touch base about housekeeping details, such as making sure everyone had copies, could answer questions for the students, and for us teachers to discuss our own teaching experiences and observations. During one meeting, we discussed the structural challenges of teaching migrant-students, such as inconsistencies in student attendance and repeated absences. A teacher commented it is difficult to push the students forward curriculum-wise when they do not attend classes. Someone else replied that these migrant domestic workers are often taken up to their employers' summer homes in the mountains for weekend-getaways, and they have no choice in the matter, they must go. Another teacher said that maybe they don't attend regularly because they feel ashamed that they have not done the homework, or feel unprepared.

Franco went on to say that he believed the students came to the Center not only to learn, but also because they felt safe here. I also commented that students liked coming here (the Migrant

${ }^{1}$ http://mwtaskforce.wordpress.com/our-initiatives/ 
Center) because they felt safe, as these students are often sexually harassed on the streets. Here, Maha, one of the volunteer coordinators said, 'This is the point of social justice. While it's important they learn, it's not always the whole point for them. It's about providing a safe and empowering space.'

\section{Reasons for volunteer-teaching}

In my interviews with other volunteer teachers, most understood the daily struggle migrant domestic workers face in a largely xenophobic society, and most of the Lebanese volunteers belong to upper-middle-class families, and, as such, they employed (and continue to employ) migrant domestic workers. Omid, a Lebanese, 21-year-old medical student recalls specific incidents from his childhood that prompted his present involvement with migrant activism:

Omid: When I was growing up, I was best friends with the domestic worker who used to work in my home. My parents were very much against that. They were like, there is classism that we cannot get over. We are from a different class than they are, they said. We should accept them but we cannot be friends. This person cannot be your best friend, you need to find friends elsewhere.

SK: So, when you were growing up, you saw these injustices... You are quite cognizant of these injustices...

Omid: I saw them, but in the end, I got... shunned by all of my surroundings my family my friends my principal at school... Even my therapist... Even my therapist told me know this cannot happen accepted. You cannot be friends with your domestic worker. In my mind that never clicked, that made no sense.

This experience affected Omid so much that he decided to participate in different groups and NGOs in Beirut that assist migrant workers. He talks about how his involvement made him come to terms with his own discrimination:

When I came to [local NGO group], I learned more about discrimination. I also discovered that maybe myself had some discrimination in my mind. I used to discriminate without knowing. And that's how I got to realize that. Later on I... From [local NGO group], that was a starting point. I got to know other human rights issues. I discovered other injustices in Lebanon.

Other volunteer teachers were prompted to volunteer due to an experience with migrants or refugees in their home countries. Twenty-six-year-old Sofia from Italy, who had lived in Syria (prior to the start of the 2011 civil war), speaks Arabic and is getting a master's degree in Islamic Studies from American University of Beirut, had volunteered at an orphanage in Burundi, Africa as a daycare worker and, in her native Italy, she volunteered as a tutor in a local high school to assist migrant students from Morocco with their schoolwork. She became very 
close to her students and visited them in their homes, which led to building relationships with the parents and other family members living in the home:

One time I was invited their home for Ramadan and they forced me to eat a lot [laughter] and I was like, "But I cannot keep eating!" And they said, "We are so happy for you to be here and eat with us." I think they were happy to have an Italian for a friend.

She relayed to me that other Italian students regularly called the Moroccan students she was tutoring racist names because they wore hijab, a form of Islamic dress that covers the hair and body, and teachers did nothing to intervene and at times even encouraged bad behaviour:

The 16-year-old, named Fatima, told me one day, "My head hurts so much." I was like, "Why?" She said, "Another student punched me in the head." I said, "Why was she punching you on the head?" And Fatima said, "Because she thinks I'm strange because I have the veil." I said, "When did this happen?" She told me, "During the class." I said, "What did the professor do?" She said, "He saw it happen, but did nothing."

By virtue of experiencing some kind of marginalization (not necessarily vis-à-vis migrant workers), either personally or by observation, has motivated volunteer teachers to participate in a cause that aligns with the migrant worker cause. Nineteen-year-old Alim, who is Lebanese and a college student majoring in Business, cites childhood bullying, especially from classmates at a young age, as a reason for wanting to get involved in the MWEG:

I don't think anyone should be treated that way. And I've had the situations, over the years, I was mistreated...by people I went to school with, or like classmates, so I know what every person might feel if he or she was mistreated. Of course it [his experience from the migrant worker experience] differs, but I like generally got an idea.

Ashraf, a Lebanese volunteer teacher is also a post-doctoral researcher and who also happens to be conducting fieldwork with migrant workers; I asked him his reasons for volunteering as a French teacher:

I really like that this teaching opportunity was suggested by Suba [the Nepali Migrant Center coordinator]. So, it was not from a Lebanese organization, to help migrants, it was more equal. And, because of this, my relations with the students is also horizontal, because it comes from Suba who used to be a migrant worker.

Ashraf commented that there are some Lebanese people whom are encouraged to volunteer in some capacity by the university career services office, which can be listed on their resume:

When you are sent from your university to do something good to benefit your CV, of course you don't have the same experience as someone else who is there for more 
altruistic reasons. Of course, the person who does it just to put it on their resume will also benefit, in some way.

\section{Building trust and relationships}

Other volunteer teachers commented on the importance of trust and building relationships with students; here, Sofia comments on trust-building:

First of all, when you want to teach someone, you need the other person to trust you. The other person has to trust you...to feel comfortable with you. So I allow joking in class, not bad jokes, but we laugh, we have to be focused, but sometimes we have five minute break, and we just talk about our lives, what we do...since I have spent time in Ethiopia, I told my Ethiopian student where I was in Ethiopia, I told her the two or three words I know in Amharic, and she was impressed, and they told me about their lives, what they do, how they feel in Lebanon, and these kinds of things. The thing I like the best is that they are really happy when they see me. When I arrive, you can actually feel they are happy to see me, it's a nice feeling.

Here, Sofia describes how she wants to protect her students from negativity and authoritarian teaching practices:

Last time in class there was a new Lebanese guy, Salim, who came to the Center to observe and help us with teaching, and he did a really bad thing...he asked Mahmoud to prounouce, "p", and Mahmoud, he did the best he could, and to me, he did prounounce it "p". But Salim, he said, "No, you are pronouncing it as if it is 'b'. Say 'p'! 'p'!" See, in Arabic, there is no "p", and Mahmoud did the best he could. And then Salim said, "The reason why you do that is because you are Egyptian, you cannot pronounce the ' $p$ ' correctly." And Mahmoud was looking at me, like, "Is it true? Do I pronounce wrong?" And I told him, "It's not true, you are pronouncing it well, you are gonna improve, and you are doing a very good job, it's fine, it's ok." I was upset, because you should not say these kinds of things, "Your pronunciation is bad because you are Egyptian." I stopped Salim when he was saying this.

What Sofia describes above about trust in the classroom parallels Omid's reflections as well:

It's very important for the students to be very comfortable with you as a teacher. And here, it's a different setting, I'm a younger person who is teaching people who are older. So this comes as a small challenge that you get over fast. They are saying you have this information... They are trusting you... So they're coming to you to get more information. 
Another classroom practice that I observed and heard in interviews was the idea of reciprocal teaching; meaning, the students were teaching the teacher as much as the teacher was teaching the students; here, Ashraf the French teacher discusses this idea:

I teach them in English, and my English is not perfect...and some of my students are Nigerian, and their English is much better than mine. Sometimes they know more English more than me. So I have to ask them, how to spell this word, or that word.... So, to them, ok, if the teacher doesn't know something, we have a kind of new equality.

Sofia mentioned reciprocity in language teaching as well:

I was teaching Mahmoud [a migrant worker from Egypt] and we started from the alphabet. I was assessing what he knew and didn't know. We were communicating in Arabic. I think that for students who can speak Arabic they are comfortable with me because my Arabic is not as good as theirs, so they feel like they are teaching me, because I always ask them questions about Arabic. For Mahmoud, I can tell, he likes that he helps me and teaches me Arabic, at the same time I'm teaching him English.

Sofia mentions how the students help and learn from each other, creating dialogue:

We discovered that in Amharic [Ethiopian language], there is no difference between "planet" and "star". So I was trying to teach Makdes, my Ethiopian student, what a star is, and she was telling me, "Sun?" and I was telling her, "Yes, 'sun' is a 'star' and she couldn't really get it. And in Arabic, they use the same word for "planet" and "star" as well. So it was interesting. So Mahmoud helped me to explain the stars are the things you see in the night sky, next to the moon. He was re-phrasing what I was saying in a way that she could grasp.

\section{Place-based curriculum}

Also significant was the idea of using place-based curriculum that contextualized the lived experiences of the migrant workers. In my interview with Abe, who taught English to students at the MWEG's Hamra location in downtown Beirut, he talked about the importance of placebased learning:

I remember looking at the EFL [English as a foreign language] textbook we were using, and it said, "John did this, Mary did that." And one of the students was like, "Why is it always 'John did this' or 'Mary did that'. Why is it never, Rahel, or Makda, or Gete [Ethiopian/Amharic names]?" I was like, "You know what? You're right. Let's change the names." So we started changing the names and working with that. And I decided that, "You know what, let's just change the whole thing." So I decided to write my own book for it. 
Abe discussed the instructional issue of homework assignments, that is, being limited as an instructor and as a student by not assigning homework. Abe feels it is counter-productive to assign homework to his students because most students are not able to complete it given their time constraints and long work hours. He feels by assigning homework, the teacher sets up the student to fail. In order to accommodate this issue, Abe structures his class to test them at the end of the class session:

Abe: So, my idea is, to give them the class, and then give them an exam right after. My attitude is "Show me what you know." So then I would correct their test, and the next session I would give them their test back.

I asked Abe his ideas about education, empowerment and activism: In his mind, why was he teaching English? What was meant to be gained for the migrant workers, seeing that they cannot earn college credit? In his opinion, is teaching an act of activism, and why?

Yes. This is a big, big big question for me. I have contemplated this a lot. I have asked myself, "Am I just helping? Or am I doing something to change? Why am I doing this?" And then I discovered something...other than the whole point of empowerment, the whole point that you're helping someone, and you're giving someone skills, that they can really use later on. With my students, I set the bar high, maybe too high. Why? Because I never wanted them to become students. I wanted them to become learners. Now, I know that, if I leave them now, and I never show up again to class, they can pick up the language by themselves. They have the tools. I was always teaching them tools. I'm really sure I can leave them, and they will continue learning. I have helped them to be independent learners. So, now, if they go back to their native countries, they can teach at least. It's not like I am only empowering them [through teaching], but they will go empower their children one day.

A case in point is Rakeb, an Ethiopian domestic worker-activist who is a student of Abe's. Abe says that Rakeb has been contacted by other Ethiopians and migrant activists from all over the world, and their language of choice to communicate is English. Abe says it would be tremendously helpful to her cause to learn English; now, she forwards the emails to Abe and he helps her with her correspondence.

I asked Abe if he himself, as an English teacher, ever brought up these issues of migrant abuse, racism, and sexism into his curriculum or classroom space?

I do incorporate it into the curriculum. On one test, for the writing assessment, I had a picture of Elizabeth Eckford, the first African-American student to be integrated into an all-white school in the United States. I asked them to write how they felt about this picture. The reading assessment was a paragraph about Elizabeth Eckford, and what she did in her life, and all the questions were on her life. Also, they had presentations. So I 
gave them a piece of difficult writing, and they had to work in pairs. I gave them dictionaries, and they had to try to understand the overall idea, decipher it. Then they had to present it to the whole class. This was an in-class graded assignment. One of the topics was on racism.

"What is racism? How do you recognize racism?" Vocabulary they came across in that piece of writing was "intentional segregation". If they didn't get it, I would sit down and explain these concepts to them. Another piece of writing they had to read and decipher was on Egypt and [Hosni] Mubarak, and another topic was the issue of the Nile and Sudan. Another topic was on floods in the Philippines, so I have tackled a lot in that level. Then, in the next level, I tackled even more social issues. So I taught them how to write an argument, and then they would have an in-class writing assignment and they would have to answer the question, "Why do you think that migrant workers should get a day off? Please write a letter to an employer explaining why migrant workers should get a day off." And, "Write a letter to your friend back home about Lebanon and if they should come here as a migrant worker." And, "Your friend has run away from her employer. Write her a letter telling her what she should do; would you convince them to go back or not?" And, then I had them do creative writing. I told them to write about anything They wanted. One wrote a fictional piece; one wrote about her childhood.

\section{Computer classes}

Omid, the medical student I mentioned earlier, taught computer classes at the MWEG downtown Beirut location. I asked him why he considers it important to teach computer literacy to migrant workers:

Computers are the link between worlds...it is technology. Discovering this technology is a big plus. Communication between migrant workers and other migrant workers and migrants and their home countries and hometowns, this is the basic way of communicating with your families and parents. So for example Skype, or Gmail, or Facebook, you can add people from your hometown, talk to them, you can have connections with them, you can talk to them, and in case there's something happening to you, it's easier to use the computer... And I have a lot of students, a lot of students who come to me and say, "Is there a way for me to get the Internet password? My madam does not give me the Internet password." Or, "I use the computer secretly when she is not at home, so I cannot use it in front of her."

I asked Omid what he taught in his classes:

Omid: I teach them several things...many come into class not even knowing how to use a computer mouse, like how to get the arrow to where you want it on the screen. Then I had students who knew the basics, and just wanted to know how to type, how to use 
Google for research, or how to use Microsoft products like Word and Excel and PowerPoint. I teach them how to utilize social media, like Facebook, how to chat, how to upload videos to YouTube, or how to open an email account, and definitely how to use Skype, so they can Skype their family back in their home countries.

SK: Did any students ask to use Photoshop?

Omid: Yes, but I don't know how to use Photoshop. But now they know how to use Google and Youtube, so they can get tutorials online to teach themselves Photoshop. But first we need the computer program.

Omid talked about his beliefs about teaching:

SK: How would you define your teaching philosophy?

Omid: I think that if I know this information, why not share it with others? And I'd like to think, maybe it's not... I hear from other people, I have a good way of sharing information... If that helps, then sure. I'm dedicated to other people. I'm dedicated to spreading this information. That's also sort of the... The medical... You know there's the certain ...oath....

SK: the Hippocratic oath?

Omid: Yes, the Hippocratic oath that says that the information that I learned, my job is to spread it around and give it to others. This information is not something I own, it's something that everybody should own. If I just happened to find it first, let me teach it to others....the [MWEG], that is what we are about, empowerment.

\section{Discussion: Freirean Pedagogy in the Teaching Spaces of the Migrant Center}

The above descriptions and narratives of critical ideology, teacher practices, curriculum content, and classroom pedagogy of volunteer teachers in migrant worker classrooms contextualized within discourses of racial and national aggression, gender inequality, and class oppression is reminiscent of the work of Paulo Freire, the critical pedagogue and educator. As a means of resistance, Freire advocated for a revolutionary pedagogy, one in which endorsed a critical view of the world.

In Freire's work with illiterate peasants he stressed the necessity of "reading the world" (Freire, 1985) instead of reading words. In his Portuguese classes, he would write a word, such as 'slum' on the board, and then he and his students would discuss its meaning and what this word represented in their lives. Essentially, he and his students were deconstructing the social meaning of words within a Marxist class analysis; in so doing, he encouraged the building of a critical consciousness by way of dialogism, which is just one aspect of a libratory and 
transformative pedagogy that seeks to counter the passivity expected of and, in essence, taught to students within the banking system of education. Here, I will outline benchmarks of a libratory pedagogy that were evident in my classroom observations and volunteer teacher interviews in the non-formal educational spaces at the Migrant Center.

\section{Reciprocity in the Teaching and Learning Process}

In several of the interviews with volunteer teachers, it was pointed out by teachers that they often called on the language expertise of their students for instructional help. For instance, Ashraf's language of choice for classroom instruction was English because it was the common language among him and his students. While Ashraf has native-level Arabic and French language skills, he admits that his English language skills are not as good as his Nigerian students' knowledge of English; he often tapped into their language expertise for assistance in explaining vocabulary words or grammar. In my observations of his class, this assistance occurred a couple of times; the students readily provided help. Also, Sofia points out that her students help her in learning Arabic. She says, "I think that for students who can speak Arabic they are comfortable with me because my Arabic is not as good as theirs, so they feel like they are teaching me, because I always ask them questions about Arabic. For Mahmoud, I can tell, he likes that he helps me and teaches me Arabic, at the same time I'm teaching him English." Sofia, Ashraf and other volunteer teachers exemplify educators who feel she or he has as much to learn from his or her students as the students learn from their teacher.

An example of reciprocity is the privileging of local funds of knowledge, which was evident when Abe responded to his students who commented on the American-type names of 'John' and 'Mary' used in the ESL text; instead of brushing off their concerns, he honored their insights by replacing the names in the textbook with Ethiopian names. He then went on to create a curriculum that responded to his students' wants and needs. According to Amanti (2005, p. 132), "This process - of developing curricula based on local knowledge - is the reverse of the typical Anglocentric curriculum developed by education specialists usually located at a great distance, spatially and conceptually, from the classroom". In doing so, we demonstrate to our students that their input, their funds of knowledge, their epistemologies, are valuable to the teaching and learning endeavor; we show, as educators, that their voices matter in every step of the education process. When educators frame themselves not as "experts", "disciplinarians", or "authority figures", but instead as simultaneous learners and teachers, believing that both positions are equally as important in the learning process, and privilege the local funds of knowledge (González, Moll, and Amanti, 2005) that students bring into the classroom space for all others, including themselves, to learn from, reciprocity in the teaching and learning process occurs (Freire, 1970). 


\section{Relationship Building and Confianza}

As mentioned by the some of the teachers, the building of relationships in the context of confianza, or mutual trust/trust development, is an important aspect to the teaching and learning experience. The notion of confianza, according to Vélez-Ibáñez and Greenberg (1992) is a "cultural construct indicating the willingness to engage in generalized reciprocity" (p. 332). This powerful concept is evidenced in Vélez-Ibáñez's (1991) political ethnography in which confianza plays a central role in the mobilization of marginalized groups, which acts as a mechanism for political and social organizing. Confianza and its importance in relationship building in educational spaces is articulated in Moll's and Arnot-Hopffer's (2005) examination of the "nature of the social relationships among administrators, teachers, and students that help establish the particular "culture"" of the school at the center of their study (p. 242); one of the findings is that trust among administrators in their teachers' pedagogical decisions is a critical component in the success of their school. Ladson-Billings (1995, p. 480) contends that, when a student feels that their teachers value them as individuals, despite their low-income status, these students excel as learners; she gives the example of a student who pointed out another student's academic shortcomings to the teacher, who rebuffed the student and gave the student in question a leadership position.

In all of these instances, confianza functions in empowering ways, whether in the realm of formal educational spaces or for the purpose of social mobilization. Within this study, Sofia also demonstrated her nature as an authentic educator by defending and protecting her students from Salim's deficit model of teaching. When students observe their teacher exhibit a caring and concerned position in regard to her students, confianza becomes established. Sofia's interaction with Salim reveals two key points: that she is vested in her students for the sake of educational growth, and also as human beings for the sake of dignity and human decency. Moll et al. (2005, p. 74) state "...[R] eciprocal practices establish serious obligations based on the assumption of confianza (mutual trust), which is reestablished or confirmed with each exchange and leads to the development of long-term relationships". The relationships being developed within Sofia's classroom between students and teacher are fomented by the mutual trust.

\section{Reflexive Thought}

Several teachers commented on how they often reflect on their classroom experiences, their motivations for teaching, and pondering the purpose of offering educational opportunities to migrant workers; Abe often asked himself, "Am I just helping? Or am I doing something to change? Why am I doing this?" Omid also asked himself similar questions regarding his curriculum: "Wait a second, what am I teaching? Is what I'm teaching really interesting? Is it really relevant?" Other volunteer teachers often reflected on their own past prejudices; Omid commented, "I also discovered that maybe myself had some discrimination in my mind. I used to discriminate without knowing. And that's how I got to realize that....from Migrant Workers 
Educational Group, that was a starting point. I got to know other human rights issues. I discovered other injustices in Lebanon." By participating in grassroots NGO work, it prompted him to confront his own discrimination.

For these teachers who lead classrooms whose students are from culturally, economically, racially, religiously, and socially different backgrounds, it is important that teachers engage in a rigorous reflexive process, as described by the volunteer teachers, especially in terms of interrogating one's own suppositions and prejudices regarding racial difference. Howard (2003, p. 196) asserts that teachers must possess "...[T]he necessary skills to critically reflect on their own racial and cultural identities and to recognize how these identities coexist with the cultural compositions of their student". Like Omid, when educators partake in the hard work of reflecting, their can root out their own biases and confront prejudice, therefore eradicating any potential racial conflicts in the classroom space.

\section{Dialogic Learning}

In the narratives above, several of the teachers and other stakeholders commented on how dialogue played an important role in their teaching; for instance, Sofia mentions that, during her five-minute classroom breaks, she and her students will talk about their lives outside of the classroom. Sofia shared with her Ethiopian student that she has been to Ethiopia and knows some Amharic. She asked her student what it's like to be a migrant worker in Beirut. Ashraf also talked about how he and his students would talk about their daily lives, and share meals outside of class time. By way of students' sharing their lived experiences, which often includes racism, sexism, and other forms of oppression, a camaraderie is formed, a sense of community, a solidarity in oppression; according to Freire (1970), it is the act of dialoguing in a shared learning space about a common social struggle that is the essence of dialogic learning. 'Dialogue' defined is:

...[T] he encounter between men, mediated by the world, in order to name the world.... Dialogue is thus an existential necessity. And since dialogue is the encounter in which the united reflection and action of the dialoguers are addressed to the world which is to be transformed and humanized, this dialogue cannot be reduced to the act of one person's "depositing" ideas in another, nor can it become a simple exchange of ideas to be "consumed" by the discussants. (Freire, 1970, p. 88-89)

In this way, dialogic learning is the framing of "dialogue" as a transformative work, one that seeks to bring to the forefront the oppressed/oppressor dichotomy; to dialogue is to engage in the "...[P]rocess that... is dedicated to the empowerment of students through disconfirming the dominant ideology of the traditional educational discourse and illuminat[e] the freedom of students to act on their world" (Darder, 1991, p. 94). A dialogic space in which students, teachers, and other community members participated contributes to an intentionality, a purpose, a deliberateness of thought and dialogue; this critical dialogic space creates the conditions for 
the fomentation of conscientização [conscientization], or critical consciousness, which contributes to foundations for new knowledge. Freire (1998, p. 100) asserts, "Dialogic experience is fundamental for building epistemological curiosity. Dialogue also implies a critical posture, it implies a preoccupation with the raison d'etre of the objects that mediates the subjects of the dialogue". In the example of Abe's students discussing in class the xenophobia and racism they encounter in Beirut, all conditions aligned to bring to fruition an activist stance and new bodies of knowledge.

\section{Implications for Education}

As mentioned previously, the basis of Freire's educational philosophy is grounded in a Marxist class analysis of the oppressor/oppressed relationship, which informed his critical pedagogical approach in the language classes he taught: he used the curriculum to decolonize the minds of his adult students. By appropriating the educational space to articulate the unequal power relations of his country, he created a libratory educational experience. The implications for radical adult education, both in an informal, NGO setting, and formal classroom setting, are meaningful. Freire's influence in adult education literature is demonstrable (2009; Pietrykowski, 1996; Kirkwood, 2011). However, Freire's place in the development literature regarding NGO education, especially in the Middle East, is not as readily available. This study provides the context for implementing Freirean pedagogy within the educational space, not just among teachers as a pedagogical practice, but also as a model for programs and management.

\section{Conclusion}

As evidenced in this article, Freirean thought is interwoven throughout this NGO's ideological functionality and the volunteer teachers' pedagogical positionality. The ideological nature of the Migrant Center epitomizes the antithesis of authoritiative and teacher-centered pedagogy and the hierarchical nature of management practices of other non-governmental organizations. As evidenced by participants' narratives, they reflect a transformative educational experience for migrant domestic workers by creating culturally responsive curriculum, dialogic teaching spaces, and the building of trust and relationships between students and teachers. Teachers exercise reflexivity and reciprocity while encouraging their students to engage in these practices, thus, modelling the very ways of being they desire in their students. In essence, an educational NGO that desires to be successful would adopt a Freirean model for its ideological structure and in its teacher pedagogy. 


\section{References}

Allman, P. (2009). Paulo Freire's Conributions to Radical Adult Education. In A. Darder, M. P. Baltodano, \& R. D. Torres (Eds.), The Critical Pedagogy Reader (pp. 417430). New York: Routledge.

“About Us.” (n.d.) الن عن Sawt Al Niswa RSS. Retrieved March 13, 2014, from http://www.sawtalniswa.com/?page $\mathrm{id}=19$

Amanti, C. (2005). "Beyond a Beads and Feathers Approach.” In N. González, L. C. Moll, and C. Amanti (Eds.), Funds of Knowledge: Theorizing Practices in Households, Communities, and Classrooms (pp. 131-142).Mahwah: Lawrence Earlbaum and Associates.

“Anti-Racism Movement: About Us.” (n.d.). Retrieved Mar 28, 2014, from http://www.antiracismmovement.com/p/about-us.html

Creswell, J. W. (2014). Research Design: Qualitative, Quantitative, and Mixed Methods Approaches (4th ed.). Thousand Oaks: SAGE Publications.

Darder, A. (1991). Culture and Power in the Classroom. Westport: Bergin and Garvey.

De Genova, N. (2005). Working the Boundaries: Race, Space, and "Illegality" in Mexican Chicago. Durham: Duke University Press.

Ethiopian Catering by Rahel in Beirut (n.d.) https://www.facebook.com/pages/Ethiopian-Catering-by-Rahel-inBeirut/251266501570123

Freire, P. (1970). Pedagogy of the Oppressed. New York: Herder and Herder.

Freire, P. (1985). "Reading the World and Reading the Word: An Interview with Paulo Freire." Language Arts. 62(1), pp. 15-21.

Freire, A. M. A. and Macedo, D. (1998). The Paulo Freire Reader. New York: The Continuum International Publishing Group.

González, N., Moll, L. C. and Amanti, C. (2005). Funds of Knowledge: Theorizing Practices in Households, Communities, and Classrooms. Mahwah: Lawrence Earlbaum and Associates.

Haeri, S. (1989). Law of Desire: Temporary Marriage in Shi'i Iran. Syracuse: Syracuse 
University Press.

Howard, T.C. (2003). “Culturally Relevant Pedagogy: Ingredients for Critical

Teacher Reflection." Theory into Practice. 42(3), pp. 195-202.

Huba, M. E. and Freed, J. E. (2000). Learner-Centered Assessment on College

Campuses: Shifting the Focus from Teaching to Learning. Boston: Allyn and Bacon.

Justice for Alem Dechasa - Migrant Workers Speak Out. (n.d.). YouTube. Retrieved July 28, 2014, from https:/www.youtube.com/watch?v=vltTwNcClx4

Kirkwood, G., \& Kirkwood, C. (2011). Living adult education: Freire in Scotland. Rotterdam: Sense.

Ladson-Billings, G. (1995). "Toward a Theory of Culturally Relevant Pedagogy." American Educational Research Journal. 32(3), pp. 465-491.

Migrant students demand 'Justice for Alem'. (n.d.). Migrant Workers Task ForceMWTF. Retrieved July 28, 2014, from http://mwtaskforce.wordpress.com/2012/03/19/migrantstudents-demand-justice-for-alem/

Moll, L. C., \& Arnot-Hopffer, E. (2005). Sociocultural Competence in Teacher Education. Journal of Teacher Education, 56(3), 242-247

NARI (Group of Nepalese Feminists in Lebanon) (n.d.). https://www.facebook.com/NARIgroup

Pietrykowski, B. (1996). Knowledge and power in adult education: Beyond Freire and Habermas. Adult Education Quarterly, 46(2), 82-97.

Rane, H. (2010). Islam and Contemporary Civilisation. Victoria: Melbourne University Publishing.

Varzi, R. (2006). Warring Souls: Youth, Media, and Martyrdom in Post-Revolution Iran. Durham: Duke University Press.

Vélez-Ibáñez, C. (1991). Rituals of marginality: politics, process, and culture change in central urban Mexico, 1969-1974. Berkeley: University of California Press.

Vélez-Ibáñez, C., \& Greenberg, J. B. (1992). Formation and Transformation of Funds of Knowledge Among U.S.-Mexican Households. Anthropology \& Education Quarterly, 23(4), 313-335. 